\title{
OPTIMALISASI MANAGEMENT BATTERY DRONE UNTUK MENINGKATKAN EFFISIENSI WAKTU TERBANG DAN PRODUKTIFITAS LUASAN IN-PIT MAPPING MENGGUNAKAN PENDEKATAN GEOMATIKA DRONE DJI PHANTOM 4 RTK DALAM KONSESI PT ARUTMIN INDONESIA
}

\author{
Sigit Putrasakti ${ }^{1)}$ \\ 1) Geologist PT Arutmin Indonesia, Departemen Mineral Resources, Balikpapan
}

\begin{abstract}
ABSTRAK
Era industri 4.0 saat ini sedang berkembang dengan pesat, hampir semua bidang industri memerlukan dan tersentuh oleh DNA utama dari era industri 4.0, yaitu automasi proses yang lebih cepat. Demikian juga dengan industri pertambangan. Pengelolaan industri pertambangan khususnya tambang batubara juga tidak luput dari praktek-praktek automasi cerdas khas industry 4.0. Salah satu terapan yang dilakukan PT Arutmin Indonesia adalah penggunaan Drone RTK (DJI Phantom 4 RTK) dalam proses in-pit mapping. Output yang akan diharapkan dari in-pit mapping menggunkan drone ini antara lain orthophoto dan kontur topografi yang bisa dimanfaatkan untuk analisis atau pekerjaan selanjutnya. Akan tetapi kendala yang dihadapi pada saat melakukan in-pit mapping menggunakan drone ini adalah keterbatasan kemampuan battery sehingga waktu terbang dan luasan yang dihasilkan dalam pemanfaatan kapasitas battery drone perlu direncanakan dengan baik. Maka diperlukan beberapa usaha yang mampu mengoptimalkan penggunaan drone dalam inpit mapping. Beberapa titik kritis yang dapat dioptimalkan kaitannya dengan management battery drone, antaranya:

1. Set ketinggian terbang

2. Kecepatan terbang

3. Overlaping foto

Ketiga praktek optimalisasi penggunaan drone tersebut mampu memaksimalkan penggunaan drone agar lebih efisiensi yaitu lama waktu terbang dan produktifitas luasan area tercapture yang meningkat, maupun memberikan rasa nyaman pilot drone dari kekhawatiran drone terjatuh. Optimalisasi ini dilakukan tentu dengan tidak meninggalkan kualitas hasil pekerjaan in-pit mapping menggunakan pendekatan geomatika drone DJI Phantom 4 RTK. Optimalisasi hal-hal tersebut di atas juga dapat dilakukan secara cepat dan praktis di lapangan, sehingga pilot drone yang sudah mengetahui typical area terbang tentu diharapkan bisa lebih baik dalam melakukan persiapan rencana terbang hingga memberikan hasil yang benar-benar maksimal.
\end{abstract}

Kata kunci: in-pit mapping, geomatika, optimalisasi drone

\begin{abstract}
The 4.0 industrial era is currently developing rapidly, almost all fields of industry require and are touched by the main DNA of the 4.0 industrial era, which is faster automation process. Likewise with the mining industry. The management of the mining industry, especially coal mines, is also not immune from 4.0 industry-specific intelligent automation practices. One of the applications made by PT Arutmin Indonesia is the use of RTK Drones (DJI Phantom 4 RTK) in the in-pit mapping process. The output expected from in-pit mapping using this drone includes orthophoto and topographic contours which can be used for further analysis or work. However, the obstacle faced when conducting in-pit mapping using this drone is the limited ability of the battery so that the flying time and the area generated in the utilization of the battery drone capacity need to be planned properly. Then some efforts are needed to optimize the use of drones in in-pit mapping. Some critical points that can be optimized in relation to battery drone management including:
\end{abstract}


1. Fly altitude set

2. $\quad$ Flying speed

3. Foto overlapping

The three practice points of optimizing the use of drones are able to maximize the use of drones to be more efficient, namely the length of time to fly and the increased productivity of the captured area, as well as providing a sense of comfort for drone pilots from fears of falling drones. This optimization is done by certainly not leaving the quality of the results of the in-pit mapping work using the DJI Phantom 4 RTK drone geomatics approach. Optimization of the things mentioned above can also be done quickly and practically in the field, so that drone pilots who already knew the typical flying area are certainly expected to be better in making flight plan preparations to provide truly maximum results.

Keywords: in-pit mapping, geomatics, drone optimization

\section{A. PENDAHULUAN}

Suatu proyek penambangan batubara merupakan sebuah industri dengan rangkaian pekerjaan yang dilakukan secara iterasi dengan cepat. Salah satu hal yang perubahannya berlangsung cepat dan mudah dikenali adalah perubahan permukaan topografi pada suatu pit yang diakibatkan oleh proses penggalian, pengangkutan maupun penimbunan material batuan, baik batuan penutup maupun batubara itu sendiri. Di sisi lain industri pertambangan juga memerlukan investasi yang tidak sedikit sehingga optimalisasi pada setiap tahapan pekerjaan perlu dilakukan guna meningkatkan efisiensinya.

Pada banyak contoh, diketehui bersama bahwa pengambilan data in-pit mapping guna mengupdate topografi di dalam pit membutuhkan waktu yang tidak sebentar dan memiliki tantangan tersendiri yaitu misalnya kondisi bukaan pit yang sudah memiliki variasi kemiringan ekstrem sehingga menyulitkan diakses personil tim ground/convensional survey secara manual maupun lalu lintas di dalam pit yang kadang sangat sibuk.

Perkembangan kemajuan teknologi bisa dimanfaatkan sebagai salah satu jalan untuk mengatasi kesulitan-kesulitan tersebut. Pemanfaatan wahana UAV (Unmanned Aerial Vehicle) yang dikombinasikan dengan pendekatan proses geomatika secara tepat bisa sedikit mengurangi ketergantungan terhadap proses convensional survey. Salah satu terapan yang dilakukan PT Arutmin Indonesia adalah penggunaan Drone RTK (DJI Phantom 4 RTK) dalam proses in-pit mapping. Output yang akan diharapkan dari in-pit mapping menggunkan drone ini antara lain orthophoto dan kontur topografi yang bisa dimanfaatkan untuk analisis atau pekerjaan selanjutnya. Beberapa keuntungan dari penggunaan Drone RTK (DJI Phantom 4 RTK) antara lain:

- Proses cepat,

- Pengoperasian mudah, automasi

- Resolusi tinggi, yaitu GSD <10 cm,

- Tidak tertutup awan

Akan tetapi kendala yang dihadapi pada saat melakukan in-pit mapping menggunakan drone ini adalah keterbatasan kemampuan battery, yaitu hanya sekitar 20 - 30 menit termasuk perjalanan sebelum dan sesudah menjalankan jalur terbangnya. Terhadap keterbatasan tersebut, perkiraan durasi waktu terbang dan luasan yang dihasilkan dalam pemanfaatan kapasitas battery drone perlu direncanakan dengan baik. Maka diperlukan beberapa usaha yang mampu mengoptimalkan penggunaan drone dalam in-pit mapping. Beberapa titik kritis yang dapat dioptimalkan kaitannya dengan management battery drone, antaranya:

1. Set ketinggian terbang

2. Kecepatan terbang

3. Overlap foto 
Operasi penerbangan drone di dalam area tambang, tetap perlu memperhatikan regulasi-regulasi yang berlaku tentang pengendalian pengoperasian sistem pesawat udara tanpa awak di ruang udara, diantaranya: Permen 180 Tahun 2015 (menggantikan Permen 90 Tahun 2015) tentang pengklasifikasian kawasan wilayah udara, Permen 163 Tahun 2015 bagian 107 mengenai peraturan keselamatan penerbangan sipil (PKPS). Terdapat juga regulasi yang memperkuat Permen 180 Tahun 2015 yaitu Permen 47 Tahun 2016 berisi bentuk pelanggaran dan sanksi.

Permen 47 Tahun 2016 juga memberikan tafsir pengoperasian drone pada uncontrolled airspace dimana rata-rata proyek tambang berada pada klasifikasi ini, maksimal diperbolehkan terbang 500 $\mathrm{ft}$ atau sekitar 150 meter di atas permukaan tanah ( 150 meter AGL - Above Ground Level)

\section{B. METODOLOGI}

Pada study kasus dimaksud dalam paper ini, pendekatan metodologi yang dilakukan adalah melakukan beberapa kali praktek menerbangkan drone dengan merubah-ubah parameter pada ketinggian drone terbang; kecepatan drone terbang dan overlap foto. Pada seluruh variasi kombinasi parameter drone terbang, dilakukan pada boundary area yang sama, digunakan secara tetap seluas 28.80 hektar, sedangkan posisi base station juga berada pada lokasi yang tetap di dalam boundary terbang tersebut.

Pada setiap variasi setting parameter percobaan drone menjalankan misi selalu dicatat data-data yang diperlukan, dari data-data yang diperoleh tersebut nantinya akan dicari kondisi setting parameter yang paling optimal dalam memanfaatkan kapasitas battery, tentu dengan memperhatikan proses geomatika selanjutnya.

Optimalisasi ini dilakukan tentu dengan tidak meninggalkan kualitas hasil pekerjaan in-pit mapping menggunakan pendekatan geomatika, karena itu komparasi hasil proses geomatika orthophoto drone dengan posisi aktual GCP (Ground Control Point) juga dilakukan. Sebaran pemasangan GCP sendiri dilakukan dengan memperhatikan prinsip keterwakilan wilayah dan pertimbangan lain untuk mendukung pendekatan proses geomatika selanjutnya, paling perlu diperhatikan adalah uji distorsi kamera. Gambar 1 merupakan sebaran posisi pemasangan GCP

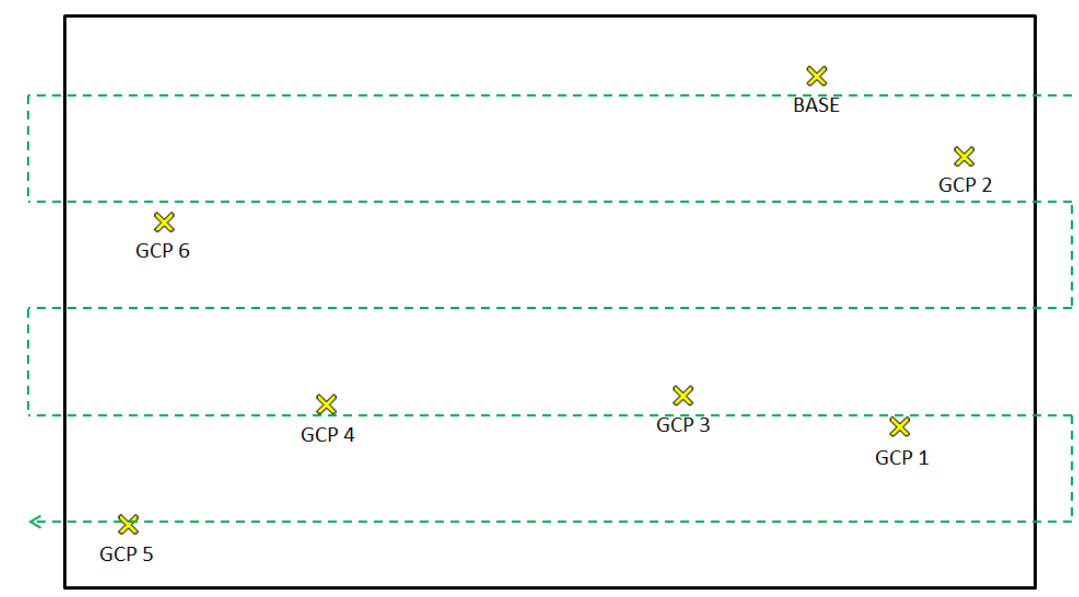

Gambar 1. Sebaran GCP \& Ilustrasi Jalur Terbang

Ketiga praktek optimalisasi penggunaan drone tersebut mampu memaksimalkan penggunaan battery drone agar lebih efisiens yaitu lama waktu terbang dan produktifitas luasan area tercapture yang meningkat, maupun memberikan rasa nyaman pilot drone dari kekhawatiran drone terjatuh.

Optimalisasi hal-hal tersebut di atas juga dapat dilakukan secara cepat dan praktis di lapangan, sehingga pilot drone yang sudah mengetahui tipe area terbang tentu diharapkan bisa lebih baik dalam melakukan persiapan rencana terbang hingga memberikan hasil yang benar-benar maksimal. Sedangkan untuk memproses data-data yang dihasilkan di lapangan pada study ini dibantu dengan software Agisoft Metashape, Global Mapper dan tentunya Microsoft Office. 


\section{HASIL DAN PEMBAHASAN}

\section{C.1. Hasil Data}

Pada study ini, data yang diambil meliputi kondisi pengaturan parameter itu sendiri (ketinggian terbang, kecepatan terbang, overlap foto), durasi waktu terbang, foto yang dihasilkan drone beserta jumlahnya dan data pendukung lainnya. Seperti disebutkan pada Bab Metodologi, lokasi pengambilan data adalah tetap yaitu disiapkan sebagai batasnya berupa 1 (satu) boundary area yang dibentuk sedemikian rupa kemudian buat dalam file * kml -salah satu jenis file yang bisa diperoleh melalui beberapa software, dalam study ini menggunakan Global Mapper-, kemudian file tersebut diupload ke dalam remote control drone. Melalui layar remote control yang sudah menampilkan boundary area tersebutlah setting jalur terbangnya drone dapat dengan mudah dilakukan.

Pengaturan ketinggian terbang drone, dilakukan untuk 3 perubahan level ketinggian above ground level yaitu 150 meter, 125 meter dan 100 meter. Pengertian ketinggian terbang adalah dihitung dari titik pertama drone diterbangkan atau pada saat drone diletakkan di atas launching pad. Tiga level ketinggian tersebut mempertimbangkan regulasi ketinggian maksimum penerbangan drone yaitu 150 meter AGL, faktor keamanan interferensi maupun obstacle pada drone jika terbang di bawah level 100 meter maupun memudahkan analisa yaitu dengan membuat perbedaan separasi level terbang per 25 meter diharapkan perubahan datanya lebih mudah dianalisa pengaruhnya.

Pada setting kecepatan terbang, juga dibagi menjadi 3 level, yaitu speed $11 \mathrm{~m} / \mathrm{s}, 9 \mathrm{~m} / \mathrm{s}$ dan $7 \mathrm{~m} / \mathrm{s}$. Namun, kecepatan $11 \mathrm{~m} / \mathrm{s}$ hanya dapat diuji coba pada ketinggian terbang 150 meter AGL karena setting pada ketinggian 125 meter dan 100 meter AGL ditolak secara default oleh sistem yang tertanam di remote control maupun drone. Begitu juga secara gradual pada speed $9 \mathrm{~m} / \mathrm{s}$ hanya dapat diuji coba pada 2 level ketinggian, 150 meter dan 125 meter, ditolak oleh default sistem terbang pada ketinggian 100 meter AGL. Sedangkan uji pengaruh overlap foto hanya dilakukan untuk 2 perbedaan overlap area foto side-forward overlap yaitu 40 - 60 dan $50-70$. Uji overlapping tidak dilakukan di atas overlap 50 - 70 dimaksudkan agar foto yang dihasilkan tidak terlalu banyak sehingga waktu pemrosesan yang diperlukan juga tidak terlalu lama. Overlapping di bawah 40-60 juga tidak dilakukan dengan tujuan agar keakuratan hasil masih bisa dipertahankan.

Seluruh pengambailan data pada semua variasi parameter dilakukan pada status satelite yang mencukupi, cuaca yang cerah dan pencahayaan yang cukup. Selain berupa foto yang akan digunakan pada proses geomatika melalui Agisoft Metashape, data statistik yang diperoleh dari uji terbang drone dapat dilihat pada Tabel 1 di bawah ini:

Tabel 1. Data Uji Terbang Terhadap Variasi Parameter

\begin{tabular}{ccccccccc}
\hline Flight & Boundary & RTK Satellite & Meter Height & Level Speed & Side Overlap & Forward Overlap & Photo & Minutes Flight \\
\hline 1 & 28.8 ha & 35 fix & 150 & 9 & 40 & 60 & 93 & $11: 20$ \\
2 & 28.8 ha & 37 fix & 125 & 9 & 40 & 60 & 128 & $12: 43$ \\
3 & 28.8 ha & 35 fix & 100 & 7 & 40 & 60 & 173 & $17: 03$ \\
4 & 28.8 ha & 36 fix & 125 & 7 & 40 & 60 & 125 & $15: 47$ \\
5 & 28.8 ha & 37 fix & 150 & 7 & 40 & 60 & 92 & $14: 06$ \\
6 & 28.8 ha & 37 fix & 150 & 11 & 40 & 60 & 97 & $9: 56$ \\
7 & 28.8 ha & 40 fix & 150 & 9 & 50 & 70 & 141 & $12: 51$ \\
8 & 28.8 ha & 41 fix & 125 & 9 & 50 & 70 & 192 & $14: 11$ \\
9 & 28.8 ha & 43 fix & 100 & 7 & 50 & 70 & 253 & $18: 41$ \\
10 & 28.8 ha & 40 fix & 125 & 7 & 50 & 70 & 185 & $17: 23$ \\
11 & 28.8 ha & 36 fix & 150 & 7 & 50 & 70 & 140 & $15: 53$ \\
12 & 28.8 ha & 37 fix & 150 & 11 & 50 & 70 & 150 & $11: 17$ \\
\hline
\end{tabular}

Seluruh foto yang dihasilkan dari uji terbang terhadap variasi parameter perlu segera di download dan dikelola dengan baik per identitas masing-masing, untuk kemudian dilakukan pengecekan 
kualitas per foto, seperti kondisinya, ukuran rata-rata foto hingga range variasi altitude. Melalui software Agisoft Metashape diproses hingga produk yang berupa orthomosaic/orthophoto. Tahapan proses dengan bantuan software tersebut dapat dilihat seperti pada Gambar 2.

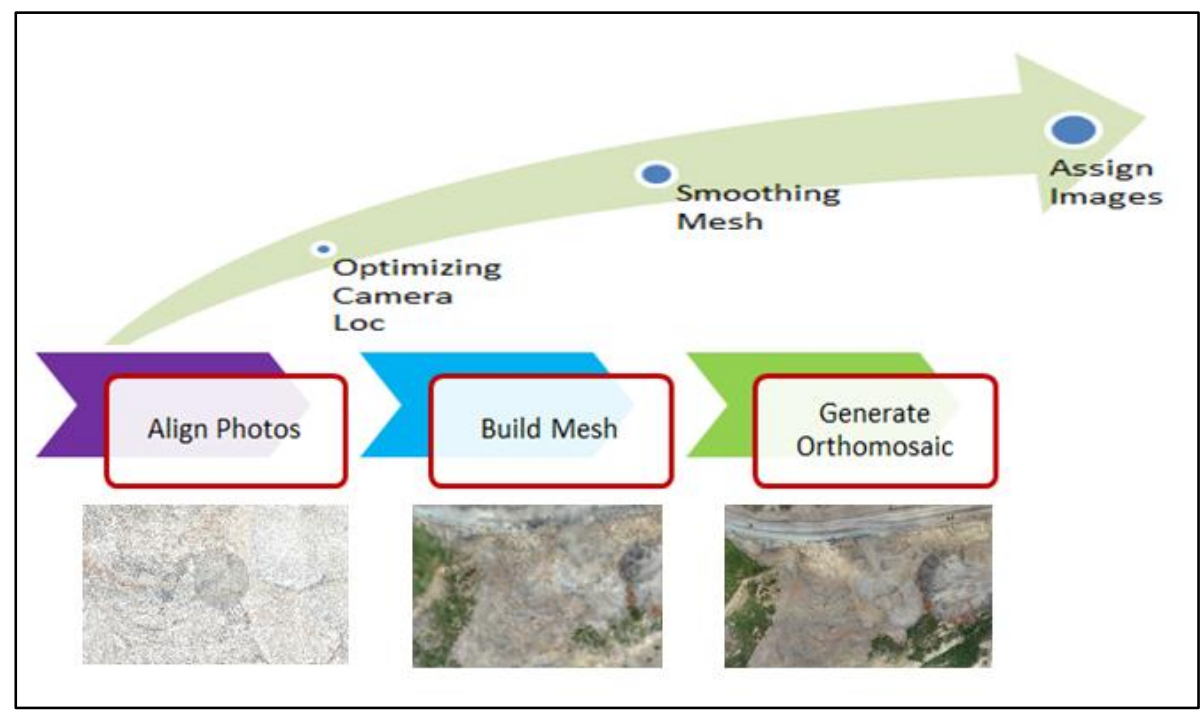

Gambar 2. Tahapan Proses Hingga Orthomosaic

Align photo dilakukan untuk mengidentifikasi titik-titik yang ada di masing-masing foto dan melakukan proses matching titik yang sama di dua atau lebih foto, menghasilkan model 3D awal, posisi kamera foto setiap perekaman dan sparse point clouds yang akan digunakan pada tahap berikutnya. Mesh adalah satu keluaran utama dari pemrosesan foto udara di Agisoft, nantinya digunakan sebagai dasar pembuatan DEM baik DSM maupun DTM dan juga orthophoto. Sedangkan orthomosaic/orthophoto adalah foto udara yang telah dikoreksi geometrinya sehingga dapat dimanfaatkan untuk kepentingan pemetaan tanpa adanya inkonsistensi skala disepanjang plan view. Waktu dalam detik, yang diperlukan pada setiap langkah utama maupun langkah pendukung (yang perlu dilakukan guna mengontrol kualitas pekerjaan) dari proses Agisoft Metashape dapat dilihat pada Tabel 2

Tabel 2. Waktu Proses dalam Detik Sampai Orthomosaic

\begin{tabular}{ccccccccc}
\hline Flight & Photo & Align Photos & Optimizing Camera & Build Mesh & Smoothing Mesh & Generate Ortho & Total Processing & Assign Images \\
\hline 1 & 93 & 512.08 & 8.70 & 12.12 & 0.02 & 308.12 & 841.03 \\
2 & 128 & $1,392.35$ & 11.09 & 17.69 & 0.03 & 230.11 & $1,651.26$ \\
3 & 173 & $1,306.55$ & 11.68 & 18.07 & 0.03 & 217.95 & $1,554.29$ \\
4 & 125 & 663.61 & 17.60 & 25.61 & 0.08 & 441.24 & $1,148.13$ \\
5 & 92 & 601.71 & 4.81 & 9.53 & 0.03 & 133.31 & 749.39 \\
6 & 97 & 769.81 & 8.22 & 7.66 & 0.02 & 276.25 & $1,061.97$ \\
7 & 141 & $1,152.81$ & 30.22 & 43.84 & 0.11 & 233.63 & $1,460.60$ \\
8 & 192 & $1,595.80$ & 20.68 & 24.81 & 0.03 & 236.71 & $1,878.03$ \\
9 & 253 & $2,365.13$ & 37.33 & 27.09 & 0.09 & 608.50 & 11 \\
10 & 185 & $1,462.59$ & 19.73 & 24.96 & 0.03 & 250.02 & 13 \\
11 & 140 & $1,146.85$ & 13.50 & 17.17 & 0.03 & 161.85 & $1,757.33$ \\
12 & 150 & $1,121.11$ & 20.06 & 20.95 & 0.03 & 215.70 & $1,339.40$ \\
\hline
\end{tabular}

\section{C.2. Pembahasan}

Dari dari Tabel 1, dapat dicermati bahwa pengaturan ketinggian terbang drone mengakibatkan perbedaan waktu terbangnya drone. Tren-nya adalah semakin tinggi level ketinggian maka diperoleh data waktu yang dibutuhkan terbang semakin sebentar. Perbandingan ini tentunya 
dibatasi oleh parameter lain yang harus sama. Flight 1 dengan flight 2 memiliki parameter speed dan overlap sama, perbedaannya pada ketinggian terbang maka dijumpai data Flight 1 yang terbang pada ketinggian 150 meter AGL lebih memerlukan waktu terbang yang sedikit (11:20 menit) dibandingkan dengan Flight 2 yang terbang pada ketinggian 124 meter AGL. Hal ini juga mencermati data Flight 3 - Flight 4 - Flight 5 yang memiliki parameter sama pada speed dan overlapping foto, semakin tinggi drone terbang, waktu yang diperlukan menyelesaikan misi lebih sedikit. Demikian juga apabila mencermati flight seterusnya.

Pengaturan ketinggian terbang memberikan pengaruh terhadap luasan area yang mampu terekam dalam foto, hal ini disebabkan seiring tingginya drone mampu memberikan cakupan area yang lebih luas pada lensa kamera drone (meski sudut bukaan lensa sama), sehingga apabila area sudah dibatasi maka semakin naiknya level ketinggian, jumlah foto yang diperlukan untuk menyelesaikan misi terbang dalam boundary tersebut akan semakin sedikit, ini berarti waktu yang dibutuhkanpun semakin sedikit. Ilustrasi pengaruh ketinggain drone terhadap cakupan area dapat dilihat pada gambar 3 berikut:

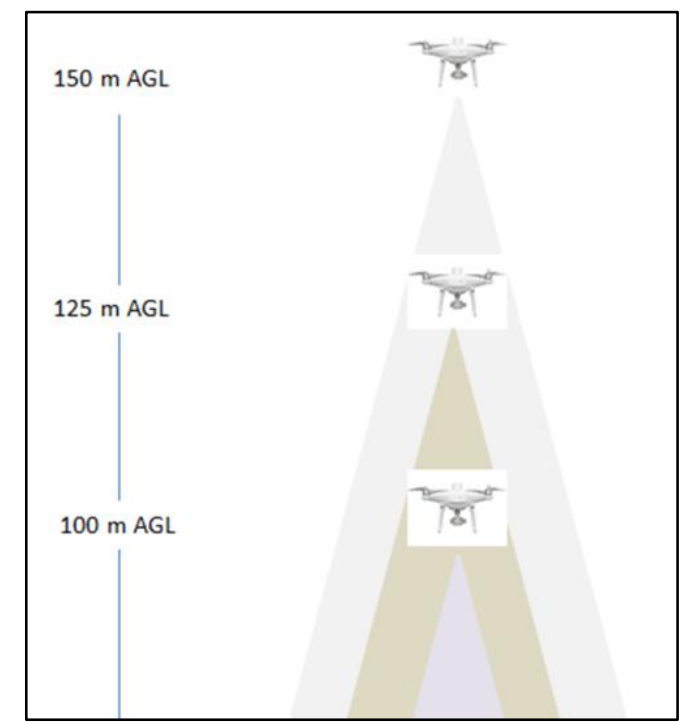

Gambar 3. Ilustrasi Pengaruh Ketinggian Terhadap Cakupan Lensa

Kecepatan terbang drone sudah barang tentu berpengaruh selaras terhadap kecepatan menyelesaikan suatu misi, ini sebagai akibat dari semakin tingginya kecepatan maka semakin jauh juga jarak yang dilintasinya pada satuan waktu yang sama. Dengan batasan parameter lain harus sama terlihat data yang diperoleh menunjukan tren yang sesuai dengan teori tersebut, membandingkan Flight 5 - Flight 1 - Flight 6 dalam Tabel 3 contohnya.

Tabel 3. Data Pengaruh Kecepatan Terhadap Waktu Terbang

\begin{tabular}{ccccccccc}
\hline Flight & Boundary & RTK Satellite & Meter Height & Level Speed & Side Overlap & Forward Overlap & Photos & Minutes Flight \\
\hline 5 & $28.8 \mathrm{ha}$ & $37 \mathrm{fix}$ & 150 & 7 & 40 & 60 & 92 & $14: 06$ \\
1 & $28.8 \mathrm{ha}$ & $35 \mathrm{fix}$ & 150 & 9 & 40 & 60 & 93 & $11: 20$ \\
6 & $28.8 \mathrm{ha}$ & $37 \mathrm{fix}$ & 150 & 11 & 40 & 60 & 97 & $9: 56$ \\
\hline
\end{tabular}

Overlap foto yang digunakan pada geomatika dikenal 2 tipe yaitu forward lap dan side lap. Forward lap adalah kemampuan kamera dalam melakukan potret yang overlap pada saat satu kali terbang di jalur track terbang yang sama, direkomendasikan adalah $70 \%$ area yang mengalami overlap dari foto pertama Side lap merupakan overlap diantara 2 garis track penerbangan yang disebut dengan spasi. Nilai khas yang diperlukan untuk proses fotogrametri adalah 30-60\%, tetapi disarankan menggunakan sedikitnya 50\% dari sisi yang terambil teorinya adalah semakin tinggi nilai overlap maka akan semakin bagus hasil olah orthophoto, terutama jika akan diolah menjadi 
3D (Liu Purnomo, 2018). Pada study ini sengaja menggunakan overlap di luar rekomendasi, memiliki tujuan sampingan juga untuk mengetahui pengaruh terhadap kualitas orthomosaic, model 3D, maupun DEM/DSM/DTM yang dihasilkan. Jika menitik beratkan pada flight time yang diperlukan untuk menyelesaikan misi, data yang diperloleh menunjukan tren semakin kecil area overlap maka semakin sedikit waktu terbang yang dibutuhkan.

Berdasarkan data pada Tabel 2. dapat diketahui bahwa total waktu proses melalui software yang paling sedikit adalah pada Flight-5 dan yang paling lama adalah pada Flight-9. Apabila dihubungkan dengan setting parameter ketinggian terbang, kecepatan terbang maupun overlap foto terdapat ketidaksesuaian dalam hubungan langsung. Setting yang menghasil waktu terbang lebih sedikit belum tentu mendapatkan waktu proses di software yang juga lebih sedikit. Satu-satunya hal yang dipertimbangkan dan selaras dalam menghasilkan waktu proses di software adalah jumlah foto.

Hal menarik lainnya adalah dijumpai hubungan selaras antara total waktu prosesing - jumlah foto dengan jumlah obyek yang tidak tepat seamlines (garis imajiner dalam Agisoft untuk melakukan sinkronisasi dalam suatu luasan tertentu), semakin sedikit waktu proses semakin banyak dijumpai ketidaksesuaian obyek, demikian juga sebaliknya semakin lama waktu proses atau semakin banyak jumlah foto maka semakin sedikit obyek yang kurang sesuai. Ketidaktepatan obyek ini memerlukan manual treatment yaitu dengan melakukan assign images. Proses menempatkan obyek secara benar ini membutuhkan ketelitian dalam mencari obyek yang bermasalah serta proses membetulkannya. Beberapa bentuk ketidaksesuaian ini seperti contoh ditampilkan pada gambar 4 berikut:
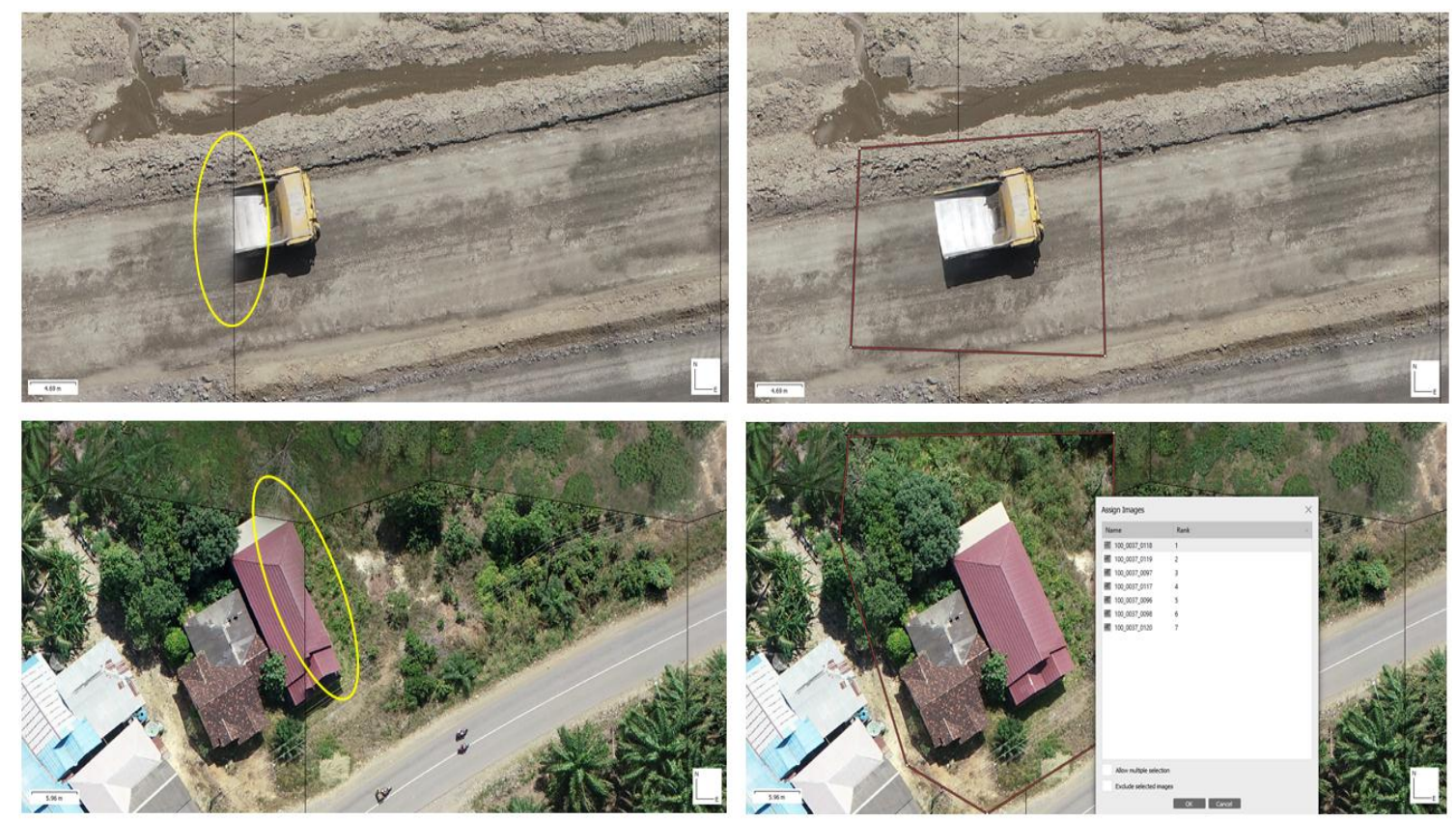

Gambar 4. Bentuk Ketidaktepatan Obyek dan Setelah Proses Assign Images

Sebagai kontrol akurasi pengolahan model 3D (DEM) dari foto hasil tangkapan drone, juga dilakukan analisa ketepatan koordinat dibandingkan dengan posisi aktual GCP dipasang. Baik di tengah boundary maupun di tepi boundary area misi terbang drone. Pemasangan GCP pada tepi boundary juga memiliki maksud untuk menguji besaran distorsi kamera (meskipun mode pengurang distorsi pada remote control drone sudah diaktifkan). Dari model DEM dapat dilakukan generate kontur sehingga posisi latitude, longitude dan altitude GCP pada orthomosaic dapat dibandingkan terhadap pengukuran posisi GCP secara ground survey. Nilai absolut selisih posisi GCP di orthomosaic dengan aktual ground survey dapat dilihat pada Tabel 4, nilai dalam meter. 
Tabel 4. Selisih Posisi GCP Orthomosaic dengan Aktual Ground Survey dalam Meter

\begin{tabular}{cccc}
\hline Flight & Variance Latitude (absolut) & Variance Longitude (absolut) & Variance Altitude (absolut) \\
\hline 1 & 0.00000291 & 0.00000258 & 1.2685 \\
2 & 0.00000323 & 0.00000259 & 1.3060 \\
3 & 0.00000264 & 0.00000155 & 0.8246 \\
4 & 0.00000288 & 0.00000185 & 1.4583 \\
5 & 0.00000324 & 0.00000407 & 1.0960 \\
6 & 0.00000159 & 0.00000362 & 1.3818 \\
7 & 0.00000289 & 0.00000233 & 0.9753 \\
8 & 0.00000287 & 0.00000103 & 0.7954 \\
9 & 0.00000189 & 0.00000215 & 0.6504 \\
10 & 0.00000316 & 0.00000233 & 0.8169 \\
11 & 0.00000332 & 0.00000292 & 0.8211 \\
12 & 0.00000317 & 0.00000369 & 0.9535 \\
\hline
\end{tabular}

Seluruh uji terbang drone, dengan variasi parameter masing-masing memberikan perbedaan latitude dan longitude yang sangat kecil, sedangkan pada altitude cukup signifikan. Trennya adalah setting pada ketinggian terbang rendah, kecepatan terbang rendah dan overlap foto lebih besar menghasilkan perbedaan altitude yang lebih kecil. Perbedaan altitude yang cukup besar ini dapat diatasi dengan melakukan penyesuaian posisi GCP pada saat awal proses di Agisoft Metashape.

\section{KESIMPULAN}

Memperhatikan kualitas, utamanya cek akurasi posisi koordinat GCP baik pada area tengah dengan distorsi kecil maupun pinggir boundary dengan distorsi kamera lebih besar, maka optimalisasi management battery drone untuk meningkatkan efisiensi waktu terbang dan produktifitas luasan inpit mapping menggunakan pendekatan geomatika drone DJI Phantom 4 RTK dapat dilakukan dengan pengoptimalan setting pada:

1. Ketinggian terbang, terbang pada level ketinggian 150 meter AGL

2. Kecepatan terbang, kecepatan $11 \mathrm{~m} / \mathrm{s}$

3. Overlaping foto, overlap 40:60

Adapun kendala pada hasil altitude yang memiliki simpangan cukup besar dapat di atasi dengan melakukuna langkah kecil berupa adjust poisisi GCP pada awal proses di dalam software Agisoft Metashape.

\section{DAFTAR PUSTAKA}

Bone, E. dan Bolkcom, C., 2003. Unmanned Aerial Vehicles: Background and Issues for Congress, Library of Congress Washington DC Conressional Research Service, United States.

Feng, Yanming and Wang, Jinling (2008) GPS RTK Performance Characteristics and Analysis, Journal of Global Positioning Systems, Vol 7. No 1.

Setiady, Joko (2013) Aplikasi GPS RTK untuk PemetaanBidang Tanah, Jurnal Online Institut Teknologi Nasional, Vol 1, No 1.

Ardhiwisesa, P., Widodo, K., Oktiawan, F (2016) Pemanfaatan Wahana Drone (DJI Phantom 4) Dengan Menggunakan Prinsip Photogrametri untuk Evaluasi Luasan dan Tutupan Lahan Area Reklamasi dalam Rangka Pemenuhan Kriteria Keberhasilan Reklamasi, PROSIDING TPT XXV PERHAPI 2016, PERHAPI. 
Ardhiwisesa, P., Oktiawan, F (2017) Optimization Usage of Drone with Photogrametry Principles for Geotechnical Monitoring and Remedial Implementation, PROCEEDINGS JOINT CONVENTION MALANG 2017, HAGI - IAGI - IAFMI - IATMI, Malang.

Prahara, Yoga (2012) Real-Time Kinematic (RTK) Positioning dan CORS, data diperoleh melalui situs internet: https://surveyoryoga.wordpress.com/2012/12/28/real-time-kinematic-rtkpositioning-dan-cors/

Riyanto, Sigit (2017) Maksimalkan Ukuran RAM pada Proses Allignment di Agisoft Fotoscan, data diperoleh melalui situs internet: https://www.sigitriyanto.com/tutorial-maksimalisasiukuran-ram-pada-proses-allignment-di-agisoft-fotoscan/

Purnomo, Liu (2018) Foto Udara dalam Pemetaan Menggunakan Drone, data diperoleh melalui situs internet: https://liupurnomo.com/foto-udara-dalam-pemetaan-menggunakan-drone/

Kemenhub (2015) Peraturan Menteri Perhubungan No. 180 Tahun 2015, data diperoleh melalui situs internet: http://jdih.dephub.go.id/assets/uudocs/permen/2015/PM_180_TAHUN_2015.pdf

Kemenhub (2015) Peraturan Menteri Perhubungan No. 163 Tahun 2015, data diperoleh melalui situs internet: http://jdih.dephub.go.id/assets/uudocs/permen/2015/PM 163 TAHUN 2015.pdf

Kemenhub (2016) Peraturan Menteri Perhubungan No. 47 Tahun 2016, data diperoleh melalui situs internet: http://jdih.dephub.go.id/assets/uudocs/permen/2016/PM_47_TAHUN_2016.pdf 
PROSIDING TPT XXVIII PERHAPI 2019 